\title{
Pengaruh Saran Bisnis Pihak Eksternal Terhadap Kinerja UKM dengan Motivasi dan Ketrampilan Manajemen sebagai variabel Mediasi
}

\author{
Trian Oktyaningrum \\ STIE Bank BPD Jateng \\ Grace Tianna Solovida \\ STIE Bank BPD Jateng
}

Lingkungan UKM memberikan kesempatan yang unik untuk mengetahui pengaruh saran bisnis pihak eksternal, motivasi, dan keterampilan manajemen terhadap kinerja UKM.Saran bisnis didefinisikan sebagai saran yang diberikan oleh pihak eksternal untuk mendukung kebutuhan informasi manajemen dalam operasi bisnis.Saran bisnis pihak eksternal yang dimaksud dalam penelitian ini berasal dari Dinas Koperasi dan UKM.Tujuan penelitian adalah untuk mengetahui dan memberikan bukti empiris pengaruh saran bisnis pihak eksternal, motivasi dan keterampilan manajemen terhadap kinerja UKM.Objek penelitian adalah Usaha Kecil dan Menengah (UKM) Binaan dari Dinas Koperasi Usaha Mikro Kota Semarang.Jumlah sampel dalam penelitian sebesar 48 UKM binaan di Kecamatan Semarang Tengah, dengan menggunakan metode purposive sampling.Sedangkan penelitian menggunakan metode analisis data yaitu SmartPLS dan pengumpulan data menggunakan kuesioner.Hasil penelitian menunjukkan bahwa saran bisnis pihak eksternal mempengaruhi secara positif terhadap kinerja UKM melalui variabel perantara yaitu motivasi dan keterampilan manajemen.

Kata Kunci: saran bisnis, motivasi, keterampilan manajemen, kinerja UKM.

\section{PENDAHULUAN}

Pertumbuhan dunia usaha semakin dikembangkan untuk mepersiapkan kehidupan yang semakin baik. Dunia usaha tidak hanya diperuntukkan untuk kalangan dewasa saja, namun remaja saat ini juga dapat terjun dalam dunia usaha. Walikota Semarang terus mendorong generasi muda untuk turut dalam mengembangkan UKM di Kota Semarang (TribunJateng.com,02 Oktober 2018). Semakin banyak yang berpartisapi dalam usaha bisnis, semakin banyak yang mendorong pertumbuhan UKM khususnya di Kota Semarang. Dengan begitu perekonomian akan semakin menguat.

Ketua Dewan Kerajinan Nasional Daerah (Dekranasda) menyampaikan deklarasi UKM Jaman Now dalam acara Gebyar UKM 2018 yang diselenggarakan oleh Dinas Koperasi dan UKM Kota Semarang. Deklarasi ini diharapkan pelaku UKM di Kota Semarang agar tidak beroperasi hanya pada tingkat kelurahan, kecamatan, dan kota saja namun untuk dapat sampai ke luar negeri (Go International). Untuk itu UKM ISSN: 2337778X jaman now menggunakan berbagai aplikasi penunjang aktivitas bisnis (TribunJateng, 02 Oktober 2018).Hal diatas menunjukkan bahwa dunia UKM telah mengalami kemajuan yang cukup pesat.

Untuk menjadi UKM Go International, maka pelaku UKM perlu memiliki kesiapan yang matang.Khususnya kesiapan baik dari material dan non material. Kesiapan material menunjukkan bahwa pemilik UKM harus memiliki cukup modal untuk menjalankan bisnis. Sedangkan kesiapan non material menunjukkan bahwa pemilik UKM harus memiliki tekad kuat, semangat dalam menjalankan usahanya. Kebutuhan akan tenaga kerja, keterampilan manajemen untuk mengelola usaha dengan baik juga perlu dipikirkan dan disiapkan oleh pemilik UKM agar operasi bisnis berjalan dengan semestinya. Ketika UKM sudah beroperasi sesuai harapan, kegiatan operasionalsatu UKM saja dapat mendorong perekonomian suatu wilayah. Sebab UKM merupakan tumpuan perekonomian bagi masyarakat, sehingga otomatis jika sistem operasional 
dalam suatu UKM itu berjalan dengan baik, maka perekonomian serta kesejahteraan masyarakat dapat tercapai.

Usaha Kecil dan Menengah (UKM) merupakan alat penggerak perekonomian negara maju dan berkembang.Banyak variasi dalam definisi UKM secara internasional. Penelitian ini mengadopsi definisi UKM menurut Kementrian Menteri Negara Koperasi dan Usaha Kecil Menengah (Menegkop dan UKM) serta Badan Pusat Statistik (BPS) bahwa UKM adalah usaha dengan kekayaan bersih paling banyak sebesar Rp 200.000.000,- tidak termasuk tanah dan bangunan tempat usaha. UKM dibagi menjadi dua kategori berdasarkan jumlah tenaga kerjanya yaitu, usaha kecil dengan jumlah tenaga kerja berkisar 5-19 orang, dan usaha menengah dengan jumlah tenaga kerja berkisar 20-99 orang (Rahmana, 2008).Indonesia sebagai salah satu negara berkembang yang UKM-nya menunjukkan pertumbuhan secara signifikan. Perekonomian di Indonesia didukung oleh pertumbuhan UKM sebesar 60 persen untuk Produk Domestik Bruto (PDB).

Pertumbuhan UKM yang sangat pesat membuat pemerintah patut bangga akan keadaan ini. Masalah perekonomian di Indonesia, seperti halnya pengangguran yang masih merajalela, mampu dikurangi dengan mengembangkan UKM.Namun, walaupun saat ini perkembangan UKM sangat pesat, masih ada kendala yang dihadapi UKM di Indonesia terutama di Kota Semarang. Walikota Semarang, Hendrar Prihadi menyatakan bahwa angka pengangguran di Kota Semarang mencapai 8,6 persen dan permasalahan yang sering dihadapi UKM adalah permodalan serta pemasaran. Permodalan dapat dibantu dengan Kredit Wibawa sedangkan pemasaran dapat dilakukan dengan memanfaatkan teknologi informasi yang ada. Angka pengangguran ini bukan terbilang kecil, oleh karena itu beliau menghimbau kepada para pengrajin atau pelaku Usaha Kecil Menengah (UKM) untuk berinovasi, serta untuk semua pihak agar membuka lapangan pekerjaan dan bersemangat untuk berwirausaha melalui UKM (Kompas, 02 Oktober 2018).
Permasalahan UKM di atas berupa permodalan dan pemasaraan merupakan hal yang melekat dengan kinerja UKM.Ketika UKM tidak memiliki cukup modal untuk membiayai kebutuhan operasional dan tidak bisa memasarkan produknya dengan baik maka kinerja UKM pun buruk.Sebab semakin cepat produk barang atau jasa itu laku maka semakin cepat organisasi itu mendapatkan uang dan dapat melangsungkan kegiatan operasionalnya. Dengan kata lain semakin cepat perputaran uang atau modal menunjukkan bahwa semakin baik kinerja dari UKM tersebut.

Berinovasi merupakan tantangan bagi Usaha Kecil dan Menengah (UKM). Untuk itu UKM seharusnya memiliki motivasi untuk maju dan keterampilan yang mumpuni agar mampu menciptakan produk unggul sesuai kebutuhan pasar. Motivasi untuk maju mungkin ada, tetapi perlu dilihat kembali bahwa UKM merupakan organisasi yang kecil dan memiliki keterbatasan sumberdaya. Keterampilanpun masih menjadi tanda tanya karena, pemilik dan karyawan mungkin terampil dalam bidang operasional tetapi belum tentu memiliki keterampilan yang mumpuni dalam dunia bisnis.

Sebagai penunjang keterampilan, pemilik UKM bisa menggunakan saran bisnis guna meningkatkan kinerja UKM.Saran bisnis ini berasal dari akuntan eksternal yang merangkum berbagai kompetensi guna mendukung sumber daya yang dibutuhkan, dan sumber potensial untuk keunggulan kompetitif UKM (Gooderham dkk., 2004). Di Indonesia, tidak ada pemisahan yang tegas antara pemilik dengan pengelola perusahaan, pemilik adalah sekaligus pengelola dalam UKM dan saran bisnis dapat diperoleh dari pihak eksternal yaitu badan pengelolaan Usaha Kecil dan Menengah dari Dinas Koperasi dan UKM (Dinkop dan UKM), dll.

Pemerintah telah memperkenalkan berbagai kebijakan, termasuk kebijakan penyediaan saran bisnis untuk memfasilitasi pembentukan perusahaan baru, dan memberikan dukungan untuk meningkatnya pertumbuhan dan kelangsungan hidup UKM (Robson dan Bannett, 2000). Kebijakan ini memberikan peluang untuk pemilik UKM mendapatkan saran bisnis secara efektif dan 
efisien.Saran bisnis dalam penelitian ini merupakan saran penunjang kebutuhan manajemen yang dibutuhkan oleh pemilik UKM untuk meningkatkan kinerja UKM. Sedangkan Johnson dkk.,(2007) mengemukakan bahwa UKM menggunakan dukungan eksternal untuk mendapat saran bisnis jika terdapat kesenjangan antara sumber daya internal yang ada dengan sumber daya yang dibutuhkan untuk mencapai tujuan bisnis suatu organisasi.

Beberapa penelitian menyatakan bahwa, saran bisnis akuntan eksternal cenderung mendukung sistem informal UKM (Coyte dkk., 2012). Seperti halnya penelitian yang dilakukan oleh Carey, (2015) di Australia, menemukan hubungan positif antara saran bisnis akuntan eksternal terhadap kinerja UKM.Penelitian sebelumnya juga menunjukkan hasil bahwa saran bisnis secara signifikan memberikan hubungan positif terhadap kinerja UKM dengan kompetensi yang dimiliki oleh akuntan eksternal (Carey dan Tanewski, 2016).Oleh karena itu saran bisnis sangat penting guna meningkatkan kinerja UKM.

Dengan adanya saran bisnis yang baik dari pihak eksternal, maka akan meningkatkan motivasi kerja untuk pemilik UKM, sehingga pemilik UKM akan termotivasi untuk meningkatkan kinerjanya. Nieman dan Nieuwenhuizen (2009), berpendapat bahwa, individu memutuskan untuk terlibat dalam kegiatan bisnis karena motivasi yang berbeda. Penelitian oleh Verheul dkk,.(2010) menunjukkan bahwa terdapat hubungan positif yang signifikan antara motivasi pengusaha berwirausaha dan kinerja perusahaan, namun Blok dan Wagner (2007), mengemukakan bahwa tidak ada hubungan yang signifikan antara motivasi pengusaha dan kinerja perusahaan.

Motivasi juga akan berpengaruh terhadap keterampilan manajemen yang dimiliki oleh pemilik UKM. Jika motivasi untuk bekerja meningkat maka pemilik UKM akan meningkatkan keterampilan manajemennya untuk kinerja UKM secara maksimal. Keterampilan manajemen yang dimiliki oleh pemilik UKM merupakan hal yang penting untuk keberhasilan UKM. Keterampilan manajemen dalam bentuk kompetensi manajerial yang diukur dengan pendidikan, pengalaman kerja, pengetahuan mengenai dunia usaha merupakan dampak positif pada kinerja UKM (Sharif dan Peou. 2008 ; Parida dkk., 2010). Penelitian sebelumnya juga berpendapat bahwa, keterampilan manajemen sumber daya yang dimiliki manajer penting untuk keberhasilan UKM, karena manajer memiliki pengaruh besar di dalam perusahan terkait keputusan strategis dan pelaksanaannya (Longenecker dkk., 2006).

Studi empiris lainnya oleh Appuhami (2007) serta Dzansi dan Dzansi (2011) menemukan hubungan signifikan antara keterampilan manajemen manajer dan kinerja perusahaan.Namun DuBrin (2012) menemukan bahwa tidak terdapat hubungan secara signifikan antara keterampilan manajerial dari manajer dan kinerja perusahaan. Penelitian sebelumnya Clarke dkk., (2010) juga mengakui bahwa bukti empiris tidak konsisten, tidak mengarah pada suatu kesimpulan mengenai hubungan antara keterampilan manajemen manajer dan kinerja perusahaan. Hal ini menjadi unik untuk dilakukan penelitian lebih lanjut.

Berdasarkan argumen-argumen dari fenomena dan penelitian terdahulu di atas, saran binsis pihak eksteral sangat membantu bagi pemilik UKM untuk tetap bertahan terhadap persaingan pasar dan mengembangkan produknya. Saran bisnis tersebut memberikan informasi penunjang kebutuhan manajemen UKM sehingga nantinya pemilik mengetahui tindakan apa yang perlu dilakukan. Dengan begitu motivasi dari pemilik pun akan meningkat dan juga berpengaruh terhadap keterampilan yang dimilikinya. Ketika motivasi meningkat diiringi dengan peningkatan keterampilan yang dimiliki oleh pemilik UKM, maka pemilik akan menunjukkan kinerja secara maksimal dan berpengaruh terhadap kinerja UKM.

Sesuai dengan perumusan masalah yang telah dijabarkan di atas, dapat diketahui tujuan dari penelitian ini adalah memberikan bukti empiris mengenai adanya pengaruh positif saran bisnis pihak eksternal terhadap kinerja UKM melalui keterampilan 
manajemen manajer dan motivasi sebagai variabel mediasi.

Penelitian ini diharapkan dapat menjadi acuan dalam pengembangan ilmu ekonomi terutama untuk konsentrasi akuntansi manajemen.Serta penelitian ini dapat memberikan kontribusi untuk para pelaku UKM di Indonesia agar bisa menerapkan saran bisnis dari pihak eksternal dengan efektif dan efisien. Penelitian ini juga bisa menjadi bahan referensi dan juga perbandingan untuk penelitian selanjutnya yang berkaitan dengan saran bisnis pihak eksternal, motivasi dan keterampilan manajemen terhadap kinerja UKM.

\section{Model Penelitian}

Model penelitian ini adalah sebagai berikut :

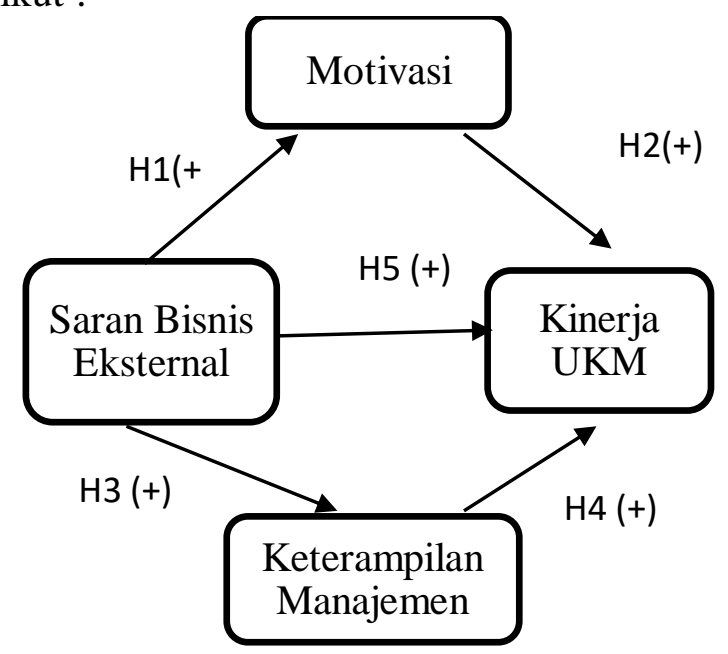

\section{Gambar 1 Model Penelitian}

\section{METODE PENELITIAN}

\section{Saran Bisnis Pihak Eksternal}

Saran bisnis pihak eksternal yang dimaksud dalam penelitian ini berasal dari Dinas Koperasi dan UKM.Saran ini juga dapat diperoleh dari pihak eksternal yaitu profesi akuntansi.Dijelaskan pada penelitian Carey (2015) dalam berbagai label termasuk 'jasa konsultasi bisnis' (BAS), 'jasa konsultasi manajemen' (MAS), atau ketika disediakan oleh auditor eksternal perusahaan, 'jasa non-audit'(NAS). Layanan yang ditawarkan oleh akuntan ekternal telah disertakan dengan baik yaitu memperluas berbagai layanan tradisional dan pengembangan layanan baru yang dirancang untuk memberikan informasi bagi pengambilan keputusan pemangku kepentingan internal.Seperti yang dikemukakan oleh Parker (2001), bahwa selama abad kedua puluh, profesi akuntansi meperluas ruang lingkup layanan yang ditawarkannya.

Menurut penelitian Carey (2015) yang merupakan acuan dalam penelitian ini, saran bisnis yang diberikan mencakup :

a. Saran yang berkaitan dengan keuangan perusahaan.

b. Perencanaan keuangan.

c. Perencanaan sistem dan kontrol

\section{Motivasi}

Verheul dkk., (2010) mendefinisikan motivasi sebagai proses yang menyumbang intensitas individu, arah dan ketekunan usaha dalam mencapai tujuan. Penelitian ini menggunakan 'motivasi' yang didefinisikan sebagai dorongan, dukungan seseorang dalam bertindak.

Indikator motivasi yang digunakan adalah indikator motivasi menurut teori kontemporer menurut McClelland dikutip Robbins (2007)diantaranya :Kebutuhan Pencapaian (Need For Achievement), Kebutuhan Kekuasaan ( Need For Power) dan Kebutuhan Hubungan (Need For Affiliation)

\section{Keterampilan Manajemen}

Penelitian ini menggunakan 'keterampilan manajemen' yang didefinisikan sebagai suatu kompetensi, pengetahuan yang diwujudkan dalam kemampuan untuk menghasilkan nilai ekonomi (Sullvian dan Sheffrin, 2003).

Keterampilan manajemen menurut Shariff dan Peou, (2008) serta Parida dkk., (2010) dilihat dari : Pendidikan, Pengalaman manajerial dan Pelatihan

\section{Kinerja}

Penelitian ini menggunakan 'kinerja' yang didefinisikan sebagai gambaran hasil kerja organisasi dalam mencapai tujuan yang juga dipengaruhi oleh sumberdaya yang ada (Jonggrang, 2012). Kinerja diukur pada tiga 
aspek menurut Robson dan Bennett, (2000) yaitu: Perubahan jumlah karyawan perusahan, perubahaan omset perusahaan dan perubahan profitabilitas atau pendapatan karyawan

Populasi penelitian adalah UKM (Usaha Kecil dan Menengah) di Kota Semarang. UKM dalam penelitian ini merupakan UKM yang dibina oleh Dinas Koperasi Mikro Kota Semarang. Penelitian ini menggunakan data IUMK (Ijin Usaha Mikro Kecil) dari Dinas Koperasi, Usaha Mikro Kota Semarangdi Kecamatan Semarang Tengah yang tercatat sebanyak 1.163 unit (Data Dinas Koperasi Usaha Mikro Kota Semarang, 2018).

Penelitian menggunakan teknik pengumpulan data metode survei.Survei dilakukan dengan menyebarkan kuesioner kepada responden yaitu UKM binaan Dinas Koperasi dan Usaha Mikro Kota Semarang di Kecamatan Semarang Tengah. Skala Likert yang digunakan dalam penelitian ini berisi 5 poin skala Likert, yaitu skala 1 menunjukkan respon yang rendah hingga skala 5 yang menunjukkan respon yang tinggi (Prabowo, 2018).

Metode analisis data yang digunakan adalah software SmartPLS.SmartPLS (Partial Least Square) merupakan analisis persamaan struktural (SEM) berbasis varian yang dapat melakukan pengujian model pengukuran sekaligus pengujian model struktural.

\section{HASIL ANALISIS DAN PEMBAHASAN}

\section{Hasil Analisis}

Berdasarkan hasil uji validitas di atas diketahui semua variabel pada setiap indikator memiliki nilai r-hitung > r-tabel maka dari itu variabel dinyatakan valid. Begitu pula dengan uji reliabilitas, dengan menggunakan cronbach alpha, menunjukkan cronbach's alpha instrumen >0,6, sehingga dapat dinyatakan reliabel.

\section{Pengujian Partial Least Squares dengan OuterModel}

Outer Model (Measurement Model) digunakan untuk mendefinisikan bagaimana setiap indikator berhubungan dengan variabel latennya.Analisa outer model dapat dilihat dari beberapa indikator: Convergent Validity, Discriminant Validity, dan Unidimensionality serta indikator memiliki hubungan yang tinggi jika memiliki nilai korelasi 0,7(Hussein, 2015). Hasil uji yang dilakukan menunjukkan setiap indikator memiliki nilai loading > 0,7 maka indikator tidak perlu untuk dihapuskan atau dikeluarkan.

Discriminant validity menunjukkan bahwa nilai cross loading faktor setiap indikator memiliki discriminant validity yang baik, yaitu nilai cross loading setiap indikator yang berbeda dengan nilai indikator dikonstruk lainnya.Discriminant validity pada tingkat indikator akan terpenuhi apabila, nilai loading semua indikator ke konstruk yang seharusnya memiliki nilai terbesar dibandingkan dengan nilai loading ke konstruk lainnya. Hal tersebut menunjukkan discriminan validity tingkat indikator terpenuhi.

Hasil Composite Reliability menunjukkan bahwa seluruh variabel memiliki reliabilitas yang tinggi yang ditunjukkan dengan nilai $>0,7$.

\section{Pengujian Partial Least Squares dengan Inner Model}

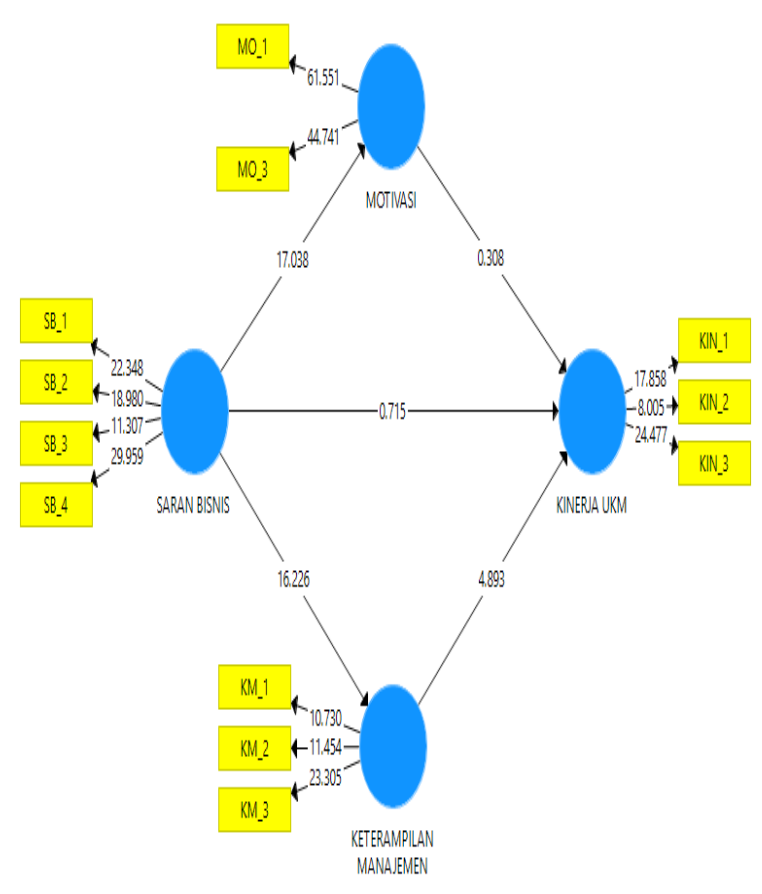

Gambar 2

Inner Model 
Berdasarkan gambar 2 di atas, menunjukkan terdapat indikator yang dihapuskan dikarenakan tidak sesuai dengan ketentuan yang ada yaitu memiliki nilai loading $>0,7$.

Uji Signifikansi

Tabel 1

Path Coefficients

\begin{tabular}{|c|c|c|}
\hline & $\begin{array}{c}\text { T Stat } \\
(|\mathrm{O} / \mathrm{STDEV}|)\end{array}$ & $\begin{array}{c}\mathbf{P} \\
\text { Values }\end{array}$ \\
\hline $\begin{array}{l}\text { KETERAMPILAN MANAJEMEN } \\
\text {-> KINERJA UKM }\end{array}$ & 4,893 & 0,000 \\
\hline MOTIVASI -> KINERJA UKM & 0,308 & 0,758 \\
\hline $\begin{array}{l}\text { SARAN BISNIS -> } \\
\text { KETERAMPILAN MANAJEMEN }\end{array}$ & 16,226 & 0,000 \\
\hline $\begin{array}{l}\text { SARAN BISNIS -> KINERJA } \\
\text { UKM }\end{array}$ & 0,715 & 0,475 \\
\hline SARAN BISNIS $->$ MOTIVASI & 17,038 & 0,000 \\
\hline
\end{tabular}

Sumber: Data primer yang diolah, 2019

Berdasarkan tabel di atas dapat diketahui diketahui bahwa:

Hasil $\mathrm{t}$ statistics menunjukkan > 1,96 yaitu $17,038>1,96$ maka terdapat pengaruh signifikan positif saran bisnis pihak eksternal meningkatkan motivasi manajer dalam operasi bisnis. Oleh karena hal tersebut di atas, $\mathrm{H1}$ diterima. Tabel menunjukkan bahwa pengaruh motivasi terhadap kinerja UKM memiliki nilai p value diatas 0,05 yaitu 0,758 $>0,05$. Hasil tersebut menjelaskan variabel motivasi tidak ada pengaruh positif secara signifikan terhadap variabel kinerja UKM.Oleh karena itu $\mathbf{H} \mathbf{2}$ ditolak.

Hipotesis 3, pengaruh saran bisnis pihak eksternal secara positif meningkatkan keterampilan manajemen manajer UKM diterima karena memiliki nilai $\mathrm{p}$ value sebesar 0,000atau $\mathrm{p}$ value $<0,05$. Kemudian $\mathrm{t}$ statistics $>1,96$ yaitu 16,226. Sedankan hipotesis 4 yang menyatakan pengaruh keterampilan manajemen secara positif meningkatkan kinerja UKM diterima. Hasil yang diperoleh dalam tabel adalah bahwa pengaruh keterampilan manajemen terhadap kinerja UKM memiliki nilai $\mathrm{p}$ value sebesar 0,000 hasil ini menunjukkan bahwa $\mathrm{p}$ value memenuhi syarat yaitu $\mathrm{p}$ value $<0,05$. Kemudian $\mathrm{t}$ statistics menunjukkan angka 4,893 artinya $\mathrm{t}$ statistics sesuai dengan ketentuan yang ada yaitu $\mathrm{t}$ statistics $>1,96$.
Hasil dalam tabel menunjukkan pengaruh saran bisnis pihak eksternal terhadap kinerja UKM memiliki nilai p value sebesar 0,475 memberikan arti bahwa $p$ value> 0,05 tidak sesuai dengan ketentuan yang ada, maka dapat dinyatakan adanya pengaruh tidak signifikan saran bisnis pihak eksternal terhadap kinerja UKM. Sedangkan t statistics menunjukkan angka 0,175 berarti $\mathrm{t}$ statistics lebih kecil dari 1,96 berbeda dengan ketentuan yang seharusnya t statistics $>1,96$. Oleh karena itu saran bisnis pihak eksternal tidak berpengaruh positif meningkatkan kinerja UKM, dan H5 ditolak.

\section{Pembahasan}

Pengaruh Saran Bisnis Pihak Eksternal secara positif meningkatkan Motivasi manajer dalam operasi bisnis.

Berdasarkan teori motivasi ekstrinsik yang dikemukakan oleh McClelland bahwa kebutuhan manusia dibagi menjadi 3 yaitu kebutuhan pencapaian, kebutuhan kekuasaan, dan kebutuhan hubungan,hal ini dapat diperoleh melalui masukan atau saran dari pihak eksternal sebagai gambaran untuk menentukan langkah kedepan yang lebih baik. Saran bisnis pihak ekstrnal sebagai sumber informasi megenai tindakan apa yang perlu dilakukan manajer UKM dalam kegiatan operasional bisnis secara efektif dan efiseien dapat meningkatkan motivasi manajer dalam kegiatan bisnis. Hasil penelitian ini mendukung penelitian Linawati (2014) terkait motivasi ektrinsik, Asah dkk., (2015), Carey dan Tanewski (2016) serta Robson dan Bennett (2000) yang menunjukkan bahwa motivasi dan saran bisnis berpengaruh positif dalam operasi bisnis.

\section{Motivasi memiliki pengaruh positif terhadap Kinerja UKM}

Hal ini dikarenakan terdapat indikator dalam kuesioner motivasi hanya membahas motivasi ekstrinsik dari manajer.Sedangkan dalam kinerja UKM tidak hanya membahas mengenai keinginan atau dorongan dari luar diri saja melainkan juga dari dalam diri manajer.Hasil penelitian ini mendukung penelitian yang telah dilakukan oleh Putra dan Frianto (2013), Linawati (2014) dan Asah 
dkk., (2015) bahwa motivasi ekstrinsik tidak berpengaruh positif terhadap kinerja UKM.

\section{Pengaruh Saran Bisnis Pihak Eksternal secara positif meningkatkan Keterampilan Manajemen manajer UKM.}

Saran bisnis dari pihak eksternal dibutuhkan oleh pemilik UKM ketika ia melihat kesenjangan antara manajer internal dengan staf internal untuk mencapai tujuan bisnis dalam suatu organisasi.Setiapadanyapeningkatan kegiatan operasional di UKM melalui saran bisnis pihak eksternal, maka hal ini tidak terlepas dari peningkatan keterampilan manajemen yang dimiliki oleh pemilik UKM.Hasil penelitian ini mendukung penelitian yang telah dilakukan oleh Asah dkk., (2015), Carey dan Tanewski (2016) yang menunjukkan bahwa saran bisnis pihak eksternal secara positif meningkatkan keterampilan manajemen manajer UKM.

\section{Pengaruh Keterampilan Manajemen secara positif meningkatkan Kinerja UKM.}

Keterampilan manajemen merupakan suatu hal penting yang harus dimiliki oleh setiap organisasi atau perusahaan. Dengan kemampuan manajemen yang tinggi akan meningkatkan inovasi produk dan penjualan produk. Akibatnya akan memberikan dampak yang signifikan pada kinerja Usaha Kecil dan Menengah secara keseluruhan.Hasil penelitian ini konsisten dengan penelitian yang sudah dilakukan oleh Asah dkk., (2015) yang menunjukkan bahwa keterampilan manajemen memiliki pengaruh positif terhadap kinerja UKM.

\section{Pengaruh Saran Bisnis Pihak Eksternal secara}

Saran bisnis pihak eksternal tidak dapat berpengaruh positif secara langsung terhadap kinerja UKM, melainkan melalui motivasi dan keterampilan manajemen yang dimiliki oleh manajer UKM sebagai perantara. Hal tersebut dijelaskan dalam Gambar 4.7 yang menunjukkan jalur pengaruh antara variabel saran bisnis pihak eksternal terhadap motivasi dan kinerja UKM, dan jalur pengaruh saran bisnis pihak eksternal terhadap keterampilan manajemen dan kinerja UKM yang masing- masing memiliki nilai lebih besar dibandingkan dengan jalur pengaruh saran bisnis pihak eksternal secara langsung ke kinerja UKM.

Penelitian ini didukung oleh penelitian Carey (2015), Carey dan Tanewski (2016) yang menyatakan bahwa saran bisnis pihak eksternal berpengaruh positif terhadap kinerja UKM. Namun besarnya pengaruh dinyatakan dalam nilai yang kecil yaitu 0,715 dibandingkan dengan besarnya pengaruh pada jalur konstruk yang lain.

\section{Kesimpulan}

Berdasarkan hasil penelitian yang telah dilakukan, maka dapat disimpulkan bahwa :

1) Terdapat pengaruh saran bisnis pihak eksternal secara positif meningkatkan motivasi manajer dalam operasi bisnis, 2) Tidak terdapat pengaruh positif motivasi terhadap kinerja UKM. 3) Terdapat pengaruh saran bisnis pihak eksternal secara positif meningkatkan keterampilan manajemen manajer UKM. 4) Terdapat pengaruh keterampilan manajemen secara positif meningkatkan kinerja UKM. 5) Tidak terdapat pengaruh positif saran bisnis pihak eksternal terhadap kinerja UKM secara langsung.

Keterbatasan dalam penelitian ini diantaranya adalah pendistribusian kuesioner ke UKM bertepatan mendekati momen natal dan tahun baru, akibatnya pemilik UKM atau yang mengelola UKM cenderung sulit untuk ditemui terkait pengisian kuesioner karena ada beberapa pemilik UKM merayakan natal, dan pengisian kuesioner tergantung pada persepsi masing-masing responden sehingga sangat tertutup.

Berdasarkan penelitian yang sudah dilaksanakan, maka penelitian ini memberikan saran kepada :

1. Pemilik UKM binaan Dinas Koperasi Usaha Mikro Kota Semarang yang sudah memiliki IUMK (Ijin Usaha Mikro Kecil), harus meningkatkan keterampilan yang dimilikinya melalui pendidikan yang tinggi, sebab dalam analisis respon responden keterampilan manajemen tergambarkan melalui indikator pendidikan dengan nilai indeks yang tinggi. Pemilik UKM juga harus memiliki motivasi yang tinggi terkait 
kebutuhan pencapaian, terutama untuk pencapaian perubahan omset perusahaan, sebab perubahan omset perusahaan merupakan indikator dengan respon yang tinggi dalam analisis respon responden. Pemilik UKM harus menggabungkan motivasi dan keterampilan yang dimilikinya untuk meningkatkan kinerja UKM.

2. Dinas Koperasi Mikro Kota Semarang harus memberikan saran bisnis terkait keuangan perusahaan guna kelancaran kelangsungan operasi bisnis UKM, karena berdasarkan analisis respon responden saran bisnis terkait keuangan perusahaan memiliki nilai indeks yang tinggi. Selanjutnya Dinas Koperasi Mikro Kota Semarang dapat memberikan saran bisnis terkait kebutuhan kekuasaan untuk meningkatkan motivasi pemilik UKM, karena berdasarkan respon responden motivasi mengenai kebutuhan kekuasaan memiliki nilai indeks yang tinggi pula.

3. Dinas Koperasi Usaha Mikro Kota Semarang harus tetap mengembangkan pelatihan-pelatihan dan fasilitasi untuk mempermudah UKM dalam mengembangkan usahanya. Dengan harapan bahwa perkembangan UKM akan semakin meningkat untuk setiap tahunnya. Karena berdasarkan analisis respon responden keterampilan pemilik UKM paling besar dapat dilihat berdasarkan pendidikannya dan kinerja UKM dapat diketahui melalui perubahan omset perusahaan sebagai tolok ukurnya.

4. Untuk penelitian selanjutnya agar dapat dilakukan mencakup seluruh wilayah Kota Semarang, sehingga dapat mengetahui perkembangan UKM secara keseluruhan, serta mencari waktu yang tepat untuk pengisian kuesioner agar bisa lebih terbuka.

5. Penelitian selanjutnya dapat mengembangkan penelitian dengan menambahkan variabel variabel lain yang mungkin juga berpengaruh terhadap kinerja UKM.

\section{DAFTAR PUSTAKA}

Achmadi, Indra. (2012), Kinerja Organisasi, tersedia http://indraachmadi.blogspot.com/2012/0 4/kinerja-organisasi.html (diakses pada 21 Desember pukul 23.08 WIB)

Appuhami, R. (2007), The Impact of Intellectul capital on investors' gains on shares: an empirical investigation of Thai Banking, finance and insurance sector, International Management Riview, Vol. 3 No. 2, pp. 14-25.

Arifin. M. Z. (2018), Pertumbuhan Jumlah UKM di Kota Semarang Rata-Rata Mencapai 2.000 Per Tahun ;TribunJateng.com (02 Oktober 2018) tersedia

http://jateng.tribunnews.com/2018/10/02/ pertumbuhan-jumlah-ukm-di-kotasemarang-rata-rata-mencapai-2000-pertahun.

(2017), Penyaluran Kredit

Wibawa Pemkot Semarang Didominasi Sektor Pedagangan; TribunJateng.com tersedia http://jateng.tribunnews.com/amp/2017/0 8/04/penyaluran-kredit-wibawa-pemkotsemarang-didominasi-sektor-pedagangan (diakses 27 Desember 2018 pukul 16.00 WIB).

\begin{tabular}{lcr} 
& .(2018), Ketua Dekranasda \\
\hline Kota Semarang & ingin UKM & Go \\
Internasional; & tersedia & di
\end{tabular}
http://jateng.tribunnews.com/2018/10/02/ ketua-dekranasda-kota-semarang-inginukm-go-internasional. . (2018), Wali Kota Semarang Dorong Generasi Muda Terjun Jadi Pengusaha UKM ; TribunJateng.com (02 Oktober 2018) tersedia di http://jateng.tribunnews.com/2018/10/02/ wali-kota-semarang-dorong-generasimuda-terjun-jadi-pengusaha-ukm.

Asah, F., Fatoki, O.O.,dan Rungani,E. (2015), The impact of motivations, personals values and management skills on the performance of SMEs in South Africa, African Journal of economic and Management Studies, Vol. 6 No. 3, pp. 308-322.

Augusty Ferdinand. (2011), Metode Penelitian Manajemen Pedoman Penelitian untuk Penulisan Skripsi, Tesis, dan Disertasi Ilmu Manajemen, Edisi 3, AGF Books, Fakultas Ekonomika dan 
Bisnis Universitas Diponegoro, Semarang.

Bahri, M.S. (2018), Pengaruh Motivasi Dan Komitmen Organisasi Terhadap Kinerja Usaha (Studi Pada Umkm Salon Pria \& Wanita Di Kecamatan Rancaekek Kabupaten Bandung), Fakultas Ekonomi dan Bisnis Universitas Pasundan Bandung, tersedia di http://repository.unpas.ac.id/32796/ (diakses pada 15 Deseber 2018).

Becker, G. (1964), Human Capital: A Theoretical and Empirical Analysis with Special Reference to Education, The University of Chicago Press, Chicago, IL.

Bennet, R.J., dan Robson, P.J.A. (2005), The advisor-SME client reationship: impact, satisfaction and commitment, Small Business Economics, Vol.25 No. 3, pp. 255-271.

Blackburn, R., dan Jarvis, R. (2010), The Role of Small and Medium Practices in Providing Business Support to Small-and Medium-sized Enterprises, A Report for the International Federationof Accountants, New York, NY, ISBN: 9781-60815-064-9, pp. 1-32.

Block, J.H. dan Sandner, P. (2009), Necessity and Opportunity Entrepreneurs and Their Duration in Self-employment: Evidence From German Micro Data, Journal of Industry, Competition and Trade, Vol. 9 No. 2, pp. 117-337.

Block, J.H., dan Wagner, M. (2007), Opportunity Recognition and Exploitation by Necessity and Opportunity Entrepreneurs: Emprical Evidence from Earnings Equation, in Solomon, G.T. (Ed.), Proceedings of The Sixty-Sixth Annual Meeting of the Academy of Management, ISSN 15438643, Philadelphia.

Bryson, J. R., Keeble, D., dan Wood, P.P.(1997), The Creation and Growth of Small Business Service Firms in PostIndustrial Britain, Small Business Economics, Vol.9,pp. 345-360.

Carey. J.P, dan Tanewski. G. (2016), The Provision Of Business Advice to SMEs by External Accountants, Managerial Auditing Journal, Vol. 31 No. 3, pp.-.
Carey. J.P. (2015), External Accountants Business Advice and SME performance, Pacific Accounting Review, Vol. 27 No. 2, pp. 166-188.

Chin, W.W. (1998). The Partial Least Square Approach for Structural Wquation Modeling.In Marcolides, G.A. (Ed). Modern Method For Business Research. Mahwah.

Choiri, E.O. (2018), Pentingnya Memiliki Ijin Usaha Mikro Kecil (IUMK) di Indonesia, Tersedia di www.jurnal.id( 08 April 2018).

Clarke, M., Seng, D., dan Whiting, R.H. (2010), Intellectual Capital and Firm Performance in Australia, Tersedia di https://otago.ourachieve.ac.nz (diakses pada 21 November 2018).

Coyte. R., Ricceri. F., dan Gutherie.J.( 2012), The Management of Knowladge Resources in SMEs : An Australian Case Study, Journals Of Knowladge Management, Vol. 16 No. 5, pp. 789-807.

Deakins, D., Logan, D., dan Steele, L. (2001), The Financial Management Of The Small Enterprise, ACCA Research Report No. 64. The Association of Chartered Certified Accountants, Certified Accountants Educational Trust, London.

Dessler, Gary. (2015), Manajemen Sumber Daya Manusia (Human Resaource Management), edisi 14, Jakarta: Salemba Empat.

DuBrin, A.J. (2012), Essential of Management, Cengage South-Western, Mason, $\mathrm{OH}$.

Dzansi, A.J., dan Dzansi, L.W. (2011), The importants of Management training topics as rated by school of managers in South Africa: Implications for training, African Journal of Business Management, Vol. 5 No.6, pp.2105-2119.

Emzir, (2012), Metodologi Penelitian Pendidikan, Jakarta: PT Raja Grafindo, Tersedia di www.academia.edu (diakses 21 November 2018).

Ferinanto, Dedi. (2017), Manajemen SDM dan Strategi Pengembangan SDM untuk UKM, tersedia di https://www.kriya.co.id/media/manajeme n-sdm-dan-strategi-pengembangan-sdmuntuk-ukm (diakses 15 Desember 2018). 
Ghozali, I. (2009),Aplikasi Analisis Multivariate dengan Program IBM SPSS 19, Semarang: Universitas Diponegoro.

Ghozali, I. (2014). Structural Equation Modeling Metode Alternatif Dengan Partial Least Square (PLS) Edisi 4. Semarang: Universitas Diponegoro Semarang.

Gooderham.P.N., Tobiassen, A., Doving, E. dan Nordhaug. O. (2004), Accountant and sources of business advice for small firm, International Small Business Journal, Vol. 22 No. 1, pp. 5-22.

Harrington, J. W., A. D. MacPherson dan Lombard, J.R.(1991),Interregional Trade in Producer Services: Review and Synthesis, Growth and Change, Vol.22, pp.75-94.

Hussein, A.S. (2015), Modul Ajar Penelitian Bisnis dan Manajemen Menggunakan Partial Least Squares (PLS) dengan smartPLS 3.0, Universitas Brawijaya.

Ilyas Yaslis. (2005), Kinerja, Teori dan Penelitian.Liberty: Yogyakarta.

Johnson. S., Webber, D.J. dan Thomas, W. (2007), Which SMEs use external business advice ?A multivariate subregional study, Environmental and Planning, Vol. 39 No. 8, pp.1981-1997.

Jonggrang, Roro. (2012),Kinerja Organisasi, Tersedia di http://raraajonggrang.blogspot.com/2012/ 10/kinerja-organisasi.html (diakses 28 Desember 2018, pukul 09.31 WIB).

Kirby, D.A., Najak, B., dan Greene, F. (1998), Accounting for growth: ways accountants can add value to small business, The Research Board, ICEW, London.

Kurniawan.A. (2018), Tekan Pengangguran Wali Kota Hendi Tingkatkan Sektor UMKM; Kompas (02 Oktober 2018).

Linawati. (2014), Pengaruh Motivasi Kerja Intrinsik dan Motivasi Kerja Ekstrinsik Terhadap Kinerja Karyawan (Studi Pada PT. Angkasa Pura 1 Bandar Udara Internasional Ahmad Yani Semarang), Sekolah Tinggi Teknologi Kedirgantaraan (STTKD) Yogyakarta,Kinerja, Volume 18, No.1, Th. 2014: Hal. 81-89.
Locke, E.A. dan Latham, G.P. (1990), A Theory of Goal Setting and Task Performance, Prentice Hall, Upper Saddle River, NJ.

Longenecker, J.G., Petty, C.W., Moore, J.W., dan Palich, L.E.(2006), Small Business Management: An Enterpreneurial Emphasis, Thomson South Western, London.

Luthans, F.(1998), Organizational Behavior, Mc. Graw-Hill.

Martin, G. and Staines, H. (2008), Managerial competencies in small firm, Tersedia di www.emraldinsight.com/insight/viewcon tentitem.do?contenttype (diakses 17 November 2018)

Nawawi,H.Hadari. (2001), Manajemen Sumber DayaManusia, Jakarta: GadjahMada University Press, tersedia di http://webcache.googleusercontent.com/s earch?q=cache:http://jurnalmahasiswa.un esa.ac.id/index.php/jim/article/download/ 2140/1311 (diakses pada 15 Desember 2018, pukul 08.23 WIB)

Nieman.G.H., dan Nieuwenhuizen. C. (2009), Entherpreneurship : A South African Persprective, Van Schalk Publishers, Pretoria.

Novitasari A. (2016), Pengaruh Budaya Organisasi Dan Motivasi Terhadap Kinerja Pegawai Unit Transfusi Darah Palang Merah Indonesia Kota Bandung, Universitas Widyatama, Skripsi, Tersedia online

https://repository.widyatama.ac.id/xmlui/ handle/123456789/8334 (diakses 15 Deseber 2018, pukul 13.15 WIB).

Parida, V., Westerberg, M., Ylinenpaa, H., dan Roininen, S. (2010), Exploring The Effect Of Network Configurations On Entrepreneurial Orientation and Firm Performance: An Emprical Study Of New Ventures And Small Firm, Annals of innovation and enterpreneurship, Vol. 1 No. 1, pp.1-13.

Parker, L. (2001), Back to The Future: The Broadening Accounting Trajectory, British Accounting Review, Vo. 33 No.4, pp. 421-453. 
Porter, M. E., (1985), Competitive Advantage: Creating and Sustaining Superior Performance, New York: The FreePress.

Power, M. (1997), The Audit Society: Rituals of Verification, Oxford University Press, New York, NY.

Prabowo, Janintra. (2018),Pengaruh Tingkat Suku Bunga Pinjaman Bank yang Menarik dan Literasi Pembukuan Terhadap Akses ke Kredit Formal Oleh UMKM Unggulan di Kota Semarang, Universitas Katolik Soegijapranata Semarang, Skripsi dipublikasikan.

Putra, A.K., dan Frianto, A. (2013), Pengaruh Motivasi Intrinsik dan Motivasi Ekstrinsik Terhadap Kepuasan Kerja, Jurnal Ilmu Manajemen, Universitas Negeri

Surabaya,http://webcache.googleusercont ent.com/search?q=cache:http://jurnalmah asiswa.unesa.ac.id/index.php/jim/article/d ownload/2140/1311 (diakses 16 Desember 2018).

Rahmana, A. (2008), Keragaman Definisi UKM di Indonesia, Tersedia di www.WordPress.com (diakses 13 Oktober 2018).

Robbins dan Judge (2007), Perilaku Organisasi, Terj. Diana Angelica. Jakarta : Salemba Empat (pp. 230 - 233, Tersedia di http://teorionline.net/teorimotivasi-kebutuhan-mcclelland/, diakses pada (04 Desember 2018).

Robson.P.J.A, dan Bennet. R.J. (2000), SME growth : The Relationship With Business Advice and External Collaboration, Small Businnes Economics, Vol. 15 No. 3, pp.193-208.

Schultz, T.W. (1961), Investment In Human Capital, The American Economic Review, Vol. 1 No. 2, pp. 1-17.

Shariff, M.N.M., dan Peou, C. (2008), The Relationship Of Entrepreneurial Value, Firm Financing and The Management and Growth Performance of SMEs in Cambodia, Problems and perspectives in Management, Vol. 6 No. 4, pp. 55-64.

Steers, R.M. (1988), Introduction to Organizational Behavior. Scott Foresman and Company.
Stoner, J.A.F., Freeman, R.E., dan J.R.,Gilbert, D.R. (1996), Manajemen, Jakarta: PT Prenhallindo.

Sugiono. (2017),Metode Penelitian Kuantitatif dan RD, Bandung: CV. Alfabeta.

Sugiyono. (2010), Metodologi Penelitian Pendidikan Pendekatan Kuantitatif, Kualitatif, dan $R \& D$, Bandung: $C V$. Afabeta, tersedia di www.ecademia.edu (diakses 21 November 2018).

Sullivan, A., dan Sheffrin, D.M. (2003), Economic Principles in Action, Pearson Prentice Hall, Upper Saddle River, NJ.

Suwatno,dan Priansa, Donni Juni. (2011), Theory and Work Motivation, Journal of OrganizationalBehavior, (online), Vol. 26, No. 331-362.

Teece, D.J., Pisano, G. \& Shuen, A. (1997),Dynamic capabilities and strategic management, Strategic Management Journal, 18(7), 509-533.

Triatna, Cepi. (2015), Perilaku Organisasi Dalam Pendidikan, Bandung: PT Remaja Rodaskarya.

Umar, H. (2003), Metodologi Riset Komunikasi Organisasi, Jakarta: PT Gramedia Pustaka Utama, Tersedia di zoraya.perlubogspot.com (diakses 21 November 2018).

Verheul. I., Thurik. R., Hessels. J., dan Van der Zwan. P. (2010), Factors Influencing The Entrepreneurial Engagement Of Opportunity and Neccesity Entrepreneurs, Scientiffic Analysis of Entrepreneurship and SMEs, Vol. 11 No. 1, pp.1-23.

Vivarelli, M. (2004), Are All The Potential Entrepreneurs So Good, Small Business Economics, Vol. 23 No. 5, pp. 41-49.

Wong, P.K., Ho, Y.P. dan Autio, E. (2005), Entrepreneurship, Innovation and Economic Growth: Evidence from GEM Data, Small Business Economics, Vol. 24 No. 4, pp. 335-350.

Yunita, N.W. (2018), Urus Ijin di Semarang hanya 4 menit, Begini caranya, Tersedia di www.detikFinance.com. 